\title{
Development Process of Intermodal Transport Solutions: The Case of Dedicated Solutions Based on Large Shippers' Volumes
}

\author{
Edith Sorkina \\ School of Business, Economics and Law, University of Gothenburg, Gothenburg, Sweden \\ Email: edith.sorkina@handels.gu.se
}

Received July 20, 2012; revised August 24, 2012; accepted September 4, 2012

\begin{abstract}
The objective of this paper is to create a process view of the development of intermodal transport solution from the basic idea to implementation. Special case of dedicated solutions based on large shippers' volumes is chosen, where the shippers engage in the development process of the new solutions. Research is conducted using a qualitative approach: multiple case studies. Empirical data has been obtained through in-depth semi-structured interviews with relevant respondents involved in the development projects. Shippers' perspective on the development process is studied. Development process can be described through a generic four-stage process: Initiation, Planning, Implementation, and Further Development. Different actors and different resources are required at the different stages. The complex process of establishing new intermodal solutions has lacked attention in the intermodal research. Understanding and improving the development process of new intermodal solutions is considered to have an important effect on the viability of intermodal transport and can help to understand the barriers that prevent companies from switching to intermodal. Development process of new dedicated intermodal solutions is a gradual process of building up the transport solution in a continuous interaction between shippers and transport service providers. Research has focused on the shipper perspective on intermodal transport, showing that switching to an intermodal transport is not simply a mode choice issue, but involves a transition process that takes time, demands resources, cooperation/coordination between multiple parties, may require changes in the supply chain beyond the transport link, involves multiple actors, and involves an industry that is itself in a process of change.
\end{abstract}

Keywords: Intermodal Transport; Case Study; Development Process; Shipper; Exploratory Study

\section{Introduction}

Intermodal transport is "the movement of goods in one and the same loading unit or vehicle, which uses successively two or more modes of transport without handling the goods themselves in changing modes [1].” The rationale of using intermodal transport is to exploit the natural advantages, the different transport modes provide, in combination. Road transport is flexible and enables high accessibility, while rail and sea/inland waterways transport allows realizing economies of scale. Moreover, intermodal transport is generally regarded as more environmentally favorable than road transportation [2].

Nevertheless, the strong political support and a clear rationale, has still resulted in a relatively low market share of intermodal transport in Europe [3] and failure to fulfill its growth expectations [4,5]. While road transport has been growing and preserves its dominant position in the intra-EU freight transport system [6], continuing concerns over the externalities from the transport sector:

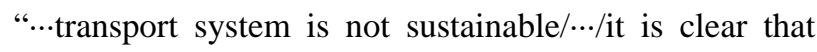
transport cannot develop along the same path [7],” whereas creating conditions for intermodal transport is still one of the key measures for making the industry more sustainable.

On the fragmented and competitive transport market a switch from one road service provider to another is not difficult, while a change from unimodal road transport solution to an intermodal one is rather complicated [5]. Substantial research exists on obtaining a better understanding of the barriers for modal shift. Barriers are often contextual and differ depending on which actors' perspective within the intermodal industry is discussed. This paper argues that from the shippers' perspective, switching to an intermodal solution is not simply matter of a mode and carrier choice decisions that could be studied through the factors that influence these decisions. Switching to an intermodal solution is a process of change that takes time, resources, involves multiple actors, and 
involves an industry that is itself in a process of change (deregulation, standardization, new actors). Thus, deeper investigation is needed that would help to understand the into the development process of new solutions. The complex process itself can be seen as one important barrier for increasing use of intermodal transport.

The paper is structured in following matter. Firstly, existing relevant literature is presented, followed by a discussion on the specific focus of this paper and the methodology applied. Then background on the empirical cases used is presented. Main part of the paper is about structured description of the development process of 3 new intermodal solutions. Finally the paper ends with discussion on the main findings and conclusion from the research.

\section{Relevant Literature}

While the development process of new intermodal solution has not been directly the focus in intermodal research, several related works should be brought to attention. Jensen $[8,9]$ has developed a process for designing and evaluating a competitive intermodal transport system and identified the characteristics the new system should possess to be attractive for the market and competitive in the long term. Moreover, the work by Bärthel and Woxenius $[10,11]$ has focused on the development of intermodal transport for small flows over short distances, presenting a case study of a pilot project. The research high lights that though the project was technically and logistically viable, intra-organizational and business strategic shortcomings severely hampered the development process.

Case study research [12] on successful application of intermodal transport solutions focuses on why different companies have shifted to intermodal transport and highlights the interaction between the intermodal solution and the companies' logistics systems. Similarly, the current research aims to study intermodal transport in the context of the supply chains, within which the new solutions are implemented.

Work by Sjöstedt et al. [13] discusses the different potential designs of intermodal transport systems in regards to the impact of two system properties-comercial openness and technological openness, on the flexibility and controllability of the intermodal system. According to the authors, openness to technologies (degree of flexibility in use of different technologies) should be designed at an early stage of system development, while commercial openness (e.g. degree of openness to different users) can be subjected to changes at later stages.

Finally, in Bergqvist et al. [14] authors focus on establishment process of new intermodal terminals-important components of intermodal solutions. Authors investigate the historical establishment process and identify factors influencing this process: profitability, location, political entrepreneur, large local shippers.

\section{Research Focus}

Traditional intermodal transport, which accounts for most of the intermodal flows, is created through market exchange processes, where carriers (supply side) are responsible for connecting transportation and the sale of the entire door-to-door transport solution to the end-customer [15]. Intermodal industry is in a process of change: new actors are emerging breaking the existing structure of monopolistic national operators [5]. For example, appearance of specialized actors in certain niche markets like the port hinterlands. This paper investigates the development process of new intermodal solutions, where large shippers with sufficient transport volumes develop and operate their own intermodal transport services. This can be considered a certain alternative to the market mechanism. This segment is found interesting, as the common problem for new intermodal solutions is how to consolidate enough freight that would make the solution economically viable. In Sweden, the potential size of this market segment is $16 \%$ - 17\% of all freight shipped (measured in volume) as that is the corresponding share of large manufacturing and wholesaling companies' freight volumes transported on distances over $300 \mathrm{~km}$ [4]. Therefore, there is a potential to shift large volumes off the road. Obviously shippers' willingness to switch is not a single factor in the change process, but an important one. Moreover, solutions developed in such a way carry the potential to develop into intermodal transport solutions open to other shippers, as the important step is to have base volumes to start with. Finally, problems associated with the increased use of intermodal transport and rail are often seen in the existing attitudes and lack of experience in the industry $[16,17]$ in terms using alternatives to road transport, thus studying these cases creates visibility and awareness of the concept.

\section{Methodology}

Research has been conducted using a qualitative approach with multiple case studies. Three case studies are conducted to avoid excessive focus on aspects that are contextual rather than generic. Nature of this study is aimed to be explorative: to look at the internal processes, not visible to outsiders, to be able to understand how new solutions are developed. Therefore, the process model used for analyzing the cases has been kept generic, and the interviews conducted for gathering empirical material have been done in a semi-structured manner that enables to preserve flexibility [18]. Cases chosen for the study are examples of dedicated solutions based on large ship- 
pers' volumes. All cases chosen are intermodal solutions with one endpoint in Sweden, as having such a common point, makes the cases more comparable due to the special geography of the region, but also common business and institutional environment. Empirical data has been mainly obtained through in-depth semi-structured interviews with relevant respondents involved in the development projects. Though an extensive interview guide had been developed in advance, the idea behind the interviews has been to obtain the "story" of the development processes, focusing on predefined aspects of the process, but also leaving room for unstructured discussion regarding the process. All in all 9 interviews have been conducted, complimented with two site visits. Data from interviews is not referenced in the text. The respondents have been mainly logistics managers both ranging from executive level to more operational, to get an understanding of different views.

\section{Process Model for Analysis}

Development process of new intermodal transport chains is studied through a generic four-stage process applicable to any new transport solution development process: Initiation (basic concept development), Planning (preparatory activities), Implementation (launch of the new solution) and Further Development (further modifications after start of operations). Such a generic view of the process has been chosen to preserve broad applicability, but still permit structured view of the process. In principal, every phase could end up in termination of the process. Figure 1 below illustrates the generic process chosen to that will be used to study of development process of new intermodal solutions.

\section{Cases}

\subsection{Volvo}

Volvo Group is one of the leading manufacturers of trucks, buses, construction equipment, drive systems for marine and industrial applications and aerospace components. Transport plays an important role in Volvo's supply chain. Firstly, Volvo has a great disadvantage against competitors as major part of operations in the Nordic region, creating long distance to suppliers and markets. Moreover, transport is part of the customer-order-manufacturing system, which means that rigid requirements in

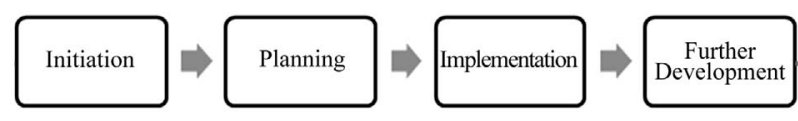

Figure 1. Generic process view to be applied in analysing the case studies. terms lead time and punctuality are placed on the transport system. Latter makes the whole system highly time sensitive and in case of delays, there is a risk of major spill-over impact on other parts of supply chain (manufacturing/assembly).

Volvo has an extensive experience of using rail from 1950s, mainly due to economies of scale advantage that rail transport enables. Rail has been used in conventional wagonload setups mainly from factory to factory, but also the company has been using an intermodal solution based on road-sea combination between Sweden and continental Europe.

The case analyzed in the paper is about the development of new intermodal transport solution for inbound transport from component suppliers in Germany to assembly plant for Volvo Group and Volvo Cars in Gothenburg, Sweden. In Germany Hanover is used as a rail hub were single wagon flows from several destination is consolidated into a block train destined to Gothenburg, pre and post carriage is done by road. Previously, same route was served $100 \%$ by unimodal road transport.

\subsection{Coop}

Coop is the second largest grocery retailer in Sweden, having a market share of around $21.5 \%$. Coop belongs to the food retail industry that is characterized by low product margins and large share of logistics costs. Operating in a highly concentrated market, with similar product range and high substitutability, the need to have the products at the right time in the right place is very important. The pressure on logistics system is also increased by the fact that large share of the product range are temperature sensitive goods.

Coop has been using rail since the 1950's, mostly wagon load transport. Coop also participated in the joint R\&D project together with competitors to investigate the potential of a collaborative intermodal solution. However, Coop stepped out of the project as a result of the top management's decision to develop an intermodal solution on its own.

The case studied in this paper involves development of a dedicated intermodal solution combining Coop's inbound flows between suppliers (manufacturers, wholesalers) in southern Sweden and main warehouses (Bro, Västeras, Enköping), and outbound flows from warehouses to stores in south of Sweden (through cross-docking terminals and directly to hypermarkets). The initial rail route has been Helsingborg-Tomteboda with a stop in Alvesta on the southbound journey. The solution covers following product groups: non-food; chilled; frozen foods; fruits. Previously the same route was mainly served both road transport, combined with wagon-load "whenever possible”. 


\subsection{Stora Enso}

Stora Enso (SE) is one of world's leading paper and pulp manufacturers. The company, as it is today, was formed through a merger of the Swedish company Stora with the Finish company Enso in 1998. Logistics and transport play an important role for the company as most of the produce from Northern Europe is exported (long distance from the markets) and the industry is highly price sensitive. Moreover, as SE belongs to a process industry with continuous manufacturing (to keep the utilization of the expensive machinery high) and transport operations are rather not time sensitive. Unitization of the cargo flow in the supply chain has been an important development in the SE's logistics system-to reduce handling damages and increase cargo density. Finally, important to mention is that SE is a major transport buyer in Swedish transport market, which has been an important factor in the decision of the Swedish Rail Authority to participate in the development project.

SE has also an extensive experience of using rail previously for connecting with the customers in continental Europe, but wagonload transport has been problematic both due to low utilization of space and risk of damage.

Intermodal solution studied in this paper involves solution connecting the mills in Sweden and Finland with customers in continental Europe and UK. Only part of the transport solution is intermodal: unitized cargo is transported from 6 Swedish mills to the port of Gothenburg via three rail connections and onward by sea to the port of Zeebrugge in Belgium. The distribution onwards from the port is not investigated as that involves stripping the cargo units and reloading cargo either to a truck or train wagons (for the European market) to be shipped to Local Distribution Centers, or loaded into other containers to be shipped overseas. Previous solution on the same route was based on wagon-load traffic between Sweden and continental Europe.

\section{Results and Analysis}

\subsection{Initiation Phase}

In a way the ideas for potentials intermodal solutions in all 3 cases were born long before the official start of the projects that led to the implementation of all 3 new intermodal solutions. In all 3 cases, prior to the approval of the new concept ideas and the official start of the development process, previous attempts of starting up new solutions using a combination of transports modes had been made, but terminated and not proceeded. In case of Coop, logistics department had previously (approx. 15 years ago) proposed to start up an intermodal solution, but due to the lack of internal support, the idea was not pursued. Similarly, Volvo made studies on a potential intermodal solution between Sweden and Germany during 2003-2004, but as the study failed to find a suitable business case and the mega trailer technology was not commercially available at the time, the idea was abandoned. Finally, SE actually set up a multimodal trial system with the use of rail and Ro-Ro ships (with handling of cargo in between), but the solution did not meet the expected results neither financially nor in terms of damages, thus was also not pursued. Though failed attempts, these studies and trial created knowledge within the companies about opportunities as well as problems in regards to intermodal solutions. Latter combined with the previous experience in rail and intermodal formed a valuable knowledge base for initiating new intermodal solutions. As highlighted in the literature, attitudes towards modes depend on the experience shippers have with the different modes and perceptions on quality and are better among those with actual experience [19]. Table 1 below summarizes the important aspects of the initiation phase.

In the initiation phase the basic idea/concept of new intermodal service is developed and gets approved. Though main work in concept development has been done by the internal logistics units within the companies investigated, the top management has played an important role in approving and supporting the concept. In case of Coop, top management actually started up the whole process. Moreover, decision was made despite the fact that at the same time Coop's logistics unit was involved in a research project evaluating the potential of an intermodal solution based on combining flows from several

Table 1. Initiation phase: Case summaries.

\begin{tabular}{|c|c|c|c|}
\hline \multirow{2}{*}{ Initiation aspect of the process } & \multicolumn{3}{|c|}{ Cases } \\
\hline & Stora Enso & Coop & Volvo \\
\hline Organizational origin of triggering idea & Logistics Department & Top Management & Logistics Department \\
\hline Actors involved in concept development & Logistics Department & Logistics Department & Logistics Department \\
\hline Organizational level of approval & $\begin{array}{c}\text { Top } \\
\text { Management }\end{array}$ & $\begin{array}{c}\text { Top } \\
\text { Management }\end{array}$ & $\begin{array}{c}\text { Top } \\
\text { Management }\end{array}$ \\
\hline Choice of the process leader & Logistics Department & Logistics Department & Logistics Department \\
\hline
\end{tabular}


grocery retailers. Involvement of the top management points to the importance of the long term perspective in making the decision to switch to intermodal transport. In case of Volvo and SE, idea originated from the logistics unit within the company and was approved by top management and received strong support throughout the development process.

Thus, the initiation stage has been mainly about internal approval of the concept, not involving other external parties. However, in case of Coop we also see the involvement of the rail operator in the concept development. Decision to build up a new intermodal solution was an outcome of negotiations with Green Cargo (the major rail operator in Sweden) to start a company together with Coop that would handle all the logistic operations for the retailer. In the dialogue between the retailer and rail operator, intermodal transport was one of the main issues discussed.

In case of Volvo, company did investigate the possibility of developing a more open solution that would be run by an external party either a railway company or a forwarder, but due to lack of interest or willingness to take the risk by an external party-Volvo decided to develop their own solution.

\subsection{Planning Phase}

Planning phase starts after the basic concept has been internally approved and the major work starts on defining the physical components of the system; defining the requirement; negotiations with existing and potential partners (service providers, equipment providers, supply chain partners, authorities); feasibility assessments (cost calculations, environmental calculations, evaluation of different alternatives); operations planning; contingency planning etc. Planning phase involves multitude of actors, both internal and external.

An important question in development of a new intermodal solution has been the issue of fit between the intermodal transport solution and the existing setups. In case of Coop, major work had been around restructuring the warehouse network to enable consolidation of freight flows. That consequently also meant renegotiations of contracts with suppliers, who were previously responsible for transport. Thus, supply chain adaptation in the form of rationalization of the warehouse network, acted as an important prerequisite for building an economically viable intermodal system. In case of SE, development of the new solution involved restructuring the European warehouse network and centralizing the transport and distribution function that was previously divided between the mills. Needed consolidation of control over freight transport within the company resulted in a major internal organization change. In case of Volvo, the fact that tran- sport is part of the customer-order-manufacturing system, stringent requirements were placed on the design of the new solution with no adaptations to the current system.

Deciding upon a load unit is an important part of the preparatory activities. In case of Volvo, there were long discussions on which equipment to use: previous investtigations (2003-2004) showed that mega trailer technology was not widely available on the market; however by 2008 situation had changed. Mega trailer was found to be most suitable because of cargo type (volume goods). As trailers were used before for road transport, there would be no change from the component suppliers' point of view. Mega trailers offered flexibility in case of disturbances-as it was easier to switch to road. In case of Coop, trailers were found useful similarly because of the flexibility to use them on road when necessary. In case of SE, load unit was developed specifically for the type of cargo transported-paper reels. Specialized cargo units were basically oversized containers. This also meant that only part of transport chain could be intermodal: the transport further on from Zeebrugge would require reloading of cargo and transporting it further to European market by means of truck or wagonload rail as the regulations outside Sweden do not permit using this type oversized cargo unit.

Finding suitable terminals was another key part of planning process. In choice of terminals, available capacity is important, but also location: to ease and reduce preand post-haulage. Finding a suitable terminal in Sweden for Volvo was a major problem and finding a solution took time. But as a result of lucky circumstances, just before start of operations opportunity presented itself and Volvo was able to purchase a terminal close to its facilities in Gothenburg. Deal was finalized a week before operations started, which meant very quick adjustments had to be made to enable taking in the whole train. For Coop and SE, initial setup involved contracting terminal operators for purchase of existing services.

Negotiations with rail operator and signing the contract has been a major step in all 3 cases as signed contracts created commitments for several years. In case of Coop, rail operator had been chosen from the start by the top-management as the initial idea was about starting up a joint company for managing all Coop's logistics needs. In case of Volvo, German operator DB was chosen instead of existing partner Green Cargo (used in another train setup), both to diversify supplier base, but also because of the main part of the journey in the new setup would be in the German rail network-it was important to get access to the German Automotive RailNet (specializing on automotive industry) system. In case of SE-the scale of the operations required to have the major rail operator on board, thus Green Cargo as the dominant rail operator in Sweden was the natural choice for partner. 
Putting in place the physical system of the intermodal solutions requires monetary commitments. In all cases, rail transport contracts had been written for full train sets, which forced the companies to bare the risk in case of underutilization of the rail capacity.

In terms of investments made, cases show combination of investments made by shipper organizations and investments made by other partners. For example, in case of Volvo haulers invested in mega trailers as they saw a new business opportunity in taking part in the intermodal setup. In case of Coop trailers were bought by Coop, similarly SE made the needed investment in the special cargo units. To enable transport of the special SE containers on rail, Swedish government invested in infrastructure adjustments-as it was seen beneficial in terms of the size of SE's transport operations and the importance of the company for the local economy. In case of Volvo, DB invested in low-built wagons, which for a major company such as DB was not a significant investment. Volvo invested in their own terminal, largely not based on choice, but rather because of lack of alternatives. In all three cases the decisions during the planning process resulted in new concepts on smaller scale than the initial idea, but with further development plans. Table 2 below summarizes the important aspects of the planning phase.

\subsection{Implementation Phase}

The implementation phase is about the official start when everything is in place and operations begin. In all cases internal logistics units that were managing the initiation and planning process remained in charge of operations after the implementation. This has meant an increased work load for all the logistics units and a lot of "new" type of work for which competences and experience had to be developed. Table 3 below summarizes the important aspects of implementation phase.

A common problem of all transport solutions is finding balances in both directions. Balancing the flows in an intermodal setup is import part of making the solution economically viable. As can be seen from the table above, all intermodal solutions are built on high utilization in one way and problematic utilization of capacity in the other direction. How imbalances have been dealt with has been discussed under the planning phase where com-

Table 2. Planning phase: case summaries.

\begin{tabular}{|c|c|c|c|}
\hline \multirow{2}{*}{$\begin{array}{l}\text { Planning aspect of } \\
\text { the process }\end{array}$} & \multicolumn{3}{|c|}{ Cases } \\
\hline & Stora Enso & Coop & Volvo \\
\hline Transport modes & Rail-sea & Rail-road & Rail-road \\
\hline $\begin{array}{l}\text { Geographical } \\
\text { coverage }\end{array}$ & Sweden (+Finland)-Belgium & Sweden & Sweden-Germany \\
\hline Load unit & Special design containers & Trailers & Mega trailers \\
\hline $\begin{array}{l}\text { Supply chain } \\
\text { adaptation }\end{array}$ & $\begin{array}{l}\text { Physical and administrational } \\
\text { changes }\end{array}$ & $\begin{array}{l}\text { Distribution network: physical and } \\
\text { administrational changes }\end{array}$ & Few changes made in lead time and delivery \\
\hline $\begin{array}{l}\text { Requirements for } \\
\text { the system }\end{array}$ & $\begin{array}{l}\text { Increased cargo density; reduced } \\
\text { vulnerability to damages; high } \\
\text { capacity system; reduced } \\
\text { environmental impact; avoiding } \\
\text { German rail network }\end{array}$ & $\begin{array}{l}\text { Strict lead times and schedule for } \\
\text { store deliveries; reduced } \\
\text { environmental impact; cost } \\
\text { level-equal or slightly less }\end{array}$ & $\begin{array}{l}\text { Reduced environmental impact; cost efficient } \\
\text { set-up; extensive use of the Automotive Rail- } \\
\text { Net; lead time-max } 48 \text { hours; attractive } \\
\text { routes and stable timetables; flexibility in } \\
\text { back-up solutions; }\end{array}$ \\
\hline $\begin{array}{l}\text { Technical } \\
\text { openness }\end{array}$ & $\begin{array}{l}\text { Train: possible to take other } \\
\text { cargo units; } \\
\text { Ship: possibility to take other } \\
\text { rolling stock is present and } \\
\text { utilized; }\end{array}$ & $\begin{array}{l}\text { Rail wagons: potentially possible to } \\
\text { take containers, but not used }\end{array}$ & $\begin{array}{l}\text { Rail wagons: can take trailers, containers, } \\
\text { swap-bodies, but only mega trailers used; }\end{array}$ \\
\hline $\begin{array}{l}\text { Commercial } \\
\text { openness }\end{array}$ & $\begin{array}{c}\text { Sea: opened up for 3rd party } \\
\text { cargo through forwarder } \\
\text { Cobelfret; } \\
\text { one external party (sold } \\
\text { production unit) using the rail } \\
\text { and sea transport and the special } \\
\text { cargo units }\end{array}$ & Closed & $\begin{array}{l}\text { Solution is designed to serve both internal and } \\
\text { an external customer (Volvo Cars) of Volvo } \\
\text { Logistics; Rail: partly extra capacity would be } \\
\text { sold to road haulers }\end{array}$ \\
\hline $\begin{array}{l}\text { Allocation of } \\
\text { financial risk }\end{array}$ & $\begin{array}{l}\text { Shipper: unit loads; rail operator } \\
\text { wagons; ship builder: vessels; } \\
\text { authority: rail infrastructure }\end{array}$ & Shipper: trailers, terminal & $\begin{array}{l}\text { Shipper: terminal; rail operator: wagons and } \\
\text { locomotives haulers: mega trailers }\end{array}$ \\
\hline
\end{tabular}


Table 3. Implementation phase: case summaries.

\begin{tabular}{|c|c|c|c|}
\hline \multirow{2}{*}{$\begin{array}{l}\text { Implementation } \\
\text { aspect of the } \\
\text { process }\end{array}$} & \multicolumn{3}{|c|}{ Cases } \\
\hline & Stora Enso & Coop & Volvo \\
\hline Back-up solution & Train-based solution to Europe & Road (using the same trailers) & $\begin{array}{l}3 \text { alternatives: road, alternative } \\
\text { train routes, road + sea }\end{array}$ \\
\hline Balance of flows & $\begin{array}{l}\text { Rail: high utilization southbound and } \\
\text { low utilization northbound; } \\
\text { Sea: balancing the flow though selling } \\
\text { out capacity (ship operating company } \\
\text { responsible) }\end{array}$ & $\begin{array}{l}\text { Rail: utilization is high on the northbound } \\
\text { flow (on the average } 80 \% \text { ), and } 60 \% \\
\text { utilization on the southbound flow }\end{array}$ & $\begin{array}{l}\text { Rail: high utilization Northbound } \\
\text { (own cargo); Southbound selling } \\
\text { out extra capacity (approx. 2/3) to } \\
\text { road haulers }\end{array}$ \\
\hline $\begin{array}{l}\text { Management of } \\
\text { day-to-day } \\
\text { operations }\end{array}$ & Logistics Unit & Logistics Unit & Logistics Unit \\
\hline
\end{tabular}

mercial openness of the intermodal solutions was put into place.

Despite the intermodal solutions being fully operational, having alternative back-up solutions in place was important in all cases. As explained above-in all 3 cases companies are highly dependent on efficient transport operations and sensitive to disturbances, latter with the exception of SE. In case of SE, the initial rail based solution was kept as back-up channel thus creating 2 alternative supply routes in connection to continental Europe. In case of Volvo and Coop, where trailers are used as load units, road is a natural alternative. Because of the sensitivity of Volvo's production system to disturbances in transport, several back-up action plans were put in place.

\subsection{Further Development Phase}

Further development describes the development and dynamic that takes place after the initial solution has been operationalized. In case of Volvo, the solution had been planned having in mind high utilization rates (especially considering that the volumes intermodal solution was supposed to cover were only $40 \%$ of the traffic between Germany and Sweden), however after the operations started in October 2008, the volumes dropped substantially and the intermodal concept dad to be reduced and redesigned to cope with the volume drop: the preparatory work was done during February-March 2009 and involved negotiations with another rail freight actor-Van Dieren (an intermodal service provider), which had a similar rail based solution suffering from drop of volumes. The new logistics solution was launched in May 2009, with both parties utilizing around $50 \%$ of the available capacity. The cooperation lasted around 1,5 years and was successful in terms enabling both companies to keep the service running, but going back to the initial setup enabled Volvo to regain the control and also there were issues with performance due to the fact that routes differed and punctually suffered. Table $\mathbf{4}$ below summarizes important aspects of the further development phase.

Overall we can see that changes can be divided into those by force: learning from experience or dealing with changed circumstances, and changes that are made because of the success of existing solution enables to consider expansion of the solution in one way or another: in terms of cargo, unit loads, nodes, etc. The main dynamics include change in the transport network and change in the commercial openness of the solution. In case of Coop and Volvo, companies are considering options to open up certain parts of the existing setup to external users. Especially as the terminal capacities are exceeding internal needs. Moreover, for Coop to make viable the expansion of network to North of part of Sweden some sort of cooperation with another shipper is needed as balance of flows on northern route is harder to achieve.

\section{Discussion and Conclusions}

The research presented in the current paper has aimed to describe the complex process of development of new intermodal solution based on large shipper volumes, where the shipper actually engages in the development and the later management of the new intermodal solution. The study is based on three cases from different industries. In all cases, shippers had a strong environmental profile; and transport and transport cost play an important role in their supply chains; and had previous experience in using rail and intermodal transport. In the cases investigated, having the internal competence and a positive experience had been stressed as an important factor in even considering the idea initially.

The complexity in terms of number of actors involved and easiness of implementing change in the logistics 
Table 4. Further development phase: case summaries.

\begin{tabular}{|c|c|c|c|}
\hline \multirow{2}{*}{$\begin{array}{c}\text { Further Development aspect } \\
\text { of the } \\
\text { process }\end{array}$} & \multicolumn{3}{|c|}{ Cases } \\
\hline & Stora Enso & Coop & Volvo \\
\hline Type of dynamics/activities & $\begin{array}{l}\text { Adding new nodes to the solution } \\
\text { (Finish mills; ports in Germany, } \\
\text { UK \& Belgium); } \\
\text { Continuous quality improvement }\end{array}$ & $\begin{array}{l}\text { Change of terminal: new terminal } \\
\text { in Bro; Change in cargo: excluding } \\
\text { fruits; Quality work: improvement } \\
\text { of the service and response to } \\
\text { disruptions; change of terminal } \\
\text { operator and adding new hauler for } \\
\text { operation in Bro }\end{array}$ & $\begin{array}{l}\text { Commercial openness changed } \\
\text { temporary - cooperation with Van } \\
\text { Dieren to deal with volume drop; } \\
\text { Studying the potential to expand } \\
\text { the solution to Russia \& widen the } \\
\text { network in Germany; Continuous } \\
\text { quality work }\end{array}$ \\
\hline $\begin{array}{l}\text { Reasons for making } \\
\text { changes }\end{array}$ & $\begin{array}{l}\text { Merger of Stora \& Enso: expanding } \\
\text { the solution to include Enso's cargo }\end{array}$ & $\begin{array}{l}\text { Problems with certain product } \\
\text { group due to tight requirements on } \\
\text { lead time and final delivery } \\
\text { windows; } \\
\text { Reducing pre-and post-haulage } \\
\text { with new terminal }\end{array}$ & $\begin{array}{c}\text { Financial situation forced to find } \\
\text { solutions for increasing the } \\
\text { utilization, thus decide to cooperate } \\
\text { with another external partner; } \\
\text { There are opportunities to expand } \\
\text { but need to investigate commercial } \\
\text { viability }\end{array}$ \\
\hline
\end{tabular}

system can differ, for instance, depending on whether the intermodal solution is implemented between units of the same company or it involves upstream/downstream supply chain partners; as a domestic or border-crossing transport solution. Either way, other external actors will be involved in developing, implementing and utilizing the solution. Collaboration with others will require negotiation in respect to responsibilities, roles, risks and costs, both externally and within the company between the departments. Different time periods from the idea development to implementation can be partly explained by complexity of the projects. In case of Coop: rail operator has been involved from the very beginning. Having the major government rail operator on the board from the start contributed to the fast progression and flexibility in terms of rail slot obtainment which is usually requiring a long process. In case of Volvo, early negotiations with DB and involvement of operational personnel ensured that "we would not discuss anything that would not work in the future". For SE case, adaptations to infrastructure and new unit load design- took considerable time.

In all cases the initial idea for the intermodal solution was on a bigger scale than the solution that actually went through the planning phase and into implementation. In case of Volvo, the initial concept covered only $40 \%$ of the volume between Germany and Sweden: both because not all volumes were efficient to consolidate, but also to have buffer for volume drops. In case of SE, initial rail based setup was kept in parallel to the new intermodal setup, plus after implementation the concept was redesigned to include Finish mills into the system. Similarly, in case of Coop, the initial idea included connections to the north of Sweden, but was at the time left aside due to lack of return volumes. Thus in all companies decision has been to be rather careful and complete concepts were supposed be put into operations in a gradual process.

In all cases, the change process has been part of change in strategic long-term planning. This long-term perspective is important for several reasons. Firstly, the projects require investments/long-term contracts for the other parties to get assurance and that requires internal support from the management. Secondly, as the scale of the changes is quite significant and the new solutions build a platform for further expansion/development, thus it needs to be supported by the vision of the future developments. In the cases investigated we can see that in one case top management has been the initiator of the whole change process and in the other 2 cases-change process has received a strong support from the management. Strong long-term commitment also means that the companies hold on to the new solutions even when problems arise in utilization of the system and quality.

Adaptations beyond the transport link had been necessary in certain cases to enable implementation of the intermodal solution. As a result of the decision to change the transport solution, Coop's the warehousing network also went through a rationalization. Thus, the intermodal transport solution was not designed to fit existing conditions in the supply chain, but the implementation of the intermodal solution had an impact beyond the transport solution. Decision to develop the intermodal solution also affected the contractual agreements with suppliers and the contract were re-written to change the terms of sale, which was a major part of the planning process. Changing the contracts and taking power over freight meant internalizing transport and logistics tasks that previously were the responsibility of suppliers, which created a lot of new tasks for the Coop Logistics not only in the planning phase of the process but also after implementationthe daily operations were run internally. In Volvo's case 
transport is part of the make-to-order manufacturing system, thus requirements on the service were kept unchanged. For SE changes involved both the restructuring of the warehousing network as well as centralization of the logistics and transport management unit within the company.

Common problem for all cases has been opening up the solution commercially or changing the commercial openness of the solution. In case of Coop, company would like to sell out the capacity of terminal, but does not have the market knowledge. Moreover, expanding the solution requires finding other shippers to cooperate with. In case of Volvo, terminal operations are not part of their core business and the decision to get involved has been made based on lack of other options.

The change to an intermodal solution and the involvement in development and running the new solution did not mean that the companies under study had "insourced" the logistics function. In all cases, companies had an existing internal logistics and transport function. However, the change meant taking up new role with new tasks both in the preparatory stage, but also later in managing the new intermodal solution.

In these specific cases investigated in the paper, shippers directly engage into buying services from transport and terminal operators, rather than a service provider selling the transport as a door-to-door product. Such solutions are built to meet the specific needs of the shipper. Extra capacity or backhaul transport could be sold to the market to increase the utilization of the solution. Developing such solutions requires certain resources (financial, time, knowledge, etc.), and thus expose the company to risks that would not be the case if intermodal solution was bought from the market (while certain risks that are present in both cases).

\section{REFERENCES}

[1] The United Nations Economic Commission for Europe, “Terminology on Combined Transport," 2001. http://www.oecd.org/sti/transport/roadtransportresearch/1 941816.pdf

[2] E. Kreutzberger, C. Macharis, L. Vereecken and J. Woxenius, "Is Intermodal Freight Transport More Environmentally Friendly Than All-Road Freight Transport: A Review,” 2003.

http://www.lir.gu.se/digitalAssets/1344/1344833_2003_n ectar_umea_kr_ma_ve_wo.pdf

[3] R. Konings, H. Priemus and P. Nijkamp, “The Future of Intermodal Freight Transport: An Overview,” In: R. Konings, H. Priemus and P. Nijkamp, Eds., The Future of Intermodal Freight Transport, Concepts, Design and Implementation, Edward Elgar Publishing, Cheltenham, 2008, pp. 1-12

[4] C. Lammgard, "Environmental Perspectives on Market- ing of Freight Transports,” Ph.D. Thesis, University of Gothenburg, Gothenburg, 2007.

[5] J. Woxenius and B. Bärthel, "Intermodal Road-Rail Transport in the European Union,” In: R. Konings, H. Priemus and P. Nijkamp, Eds., The Future of Intermodal Freight Transport, Concepts, Design and Implementation, Edward Elgar Publishing, Cheltenham, UK, 2008, pp. 13-33.

[6] European Commission, "EU transport in figures," 2011. http://ec.europa.eu/transport/publications/statistics/doc/20 11/pocketbook2011.pdf

[7] European Commission, "White Paper: Roadmap to a Single European Transport Area-Towards a Competitive and Resource Efficient Transport System,” 2011. http://eur-lex.europa.eu/LexUriServ/LexUriServ.do?uri= COM:2011:0144:FIN:en:PDF

[8] A. Jensen, "Combined Transport: Systems, Economics and Strategies,” The Swedish Transport Research Board, Stockholm, 1990.

[9] A. Jensen, "Designing Intermodal Transport Systems: A Conceptual and Methodological Framework," In: R. Konings, H. Priemus and P. Nijkamp, Eds., The Future of Intermodal Freight Transport, Concepts, Design and Implementation, Edward Elgar Publishing, Cheltenham, UK, 2008, pp. 187-205.

[10] F. Bärthel and J. Woxenius, “The Dalecarlian Girl— Evaluation of the Implementation of the Light-Combi Concept,” 2003.

http://www.fek.handels.gu.se/digitalAssets/1344/1344831 _2003_ags_tokyo_dalkullan.pdf

[11] F. Bärthel and J. Woxenius, "Developing Intermodal Transport for Small Flows Over Short Distances,” Journal of Transportation Planning and Technology, Vol. 27, No. 5, 2004, pp. 403-424. doi:10.1080/0308106042000287586

[12] F. E. Larsson and D. Kollberg, "Overcoming the Obstacles of Intermodal Transport-A Shipper Perspective on the Effects of Modal Shift,” Master Thesis, University of Lund, Lund, 2009.

[13] L. Sjöstedt, J. Woxenius and L. Hulten, "Flexibility versus Specialization on the Controllability of Combined Transport Systems,” 1994.

http://130.241.192.19/Files/foretagsekonomi/LoT/Johan/P ublitions/Reviewed_articles/1994_IFAC_Controllability.pdf

[14] R. Bergqvist, G. Falkemark and J. Woxenius, "Establishing Intermodal Terminals," World Review of Intermodal Transportation Research, Vol. 3, No. 3, 2010, pp. 286302. doi:10.1504/WRITR.2010.034667

[15] R. Bergqvist, J. Birgander, F. Bärthel, A. Jensen, P. O. Persson and J. Thalenius, "Nya Aspekter På Intermodala Transportkedjor,” 2008. www.sir-c.se/getfile. ashx?cid=257832\&cc $=3 \&$ refid=26

[16] European Commission, "Study on Freight Integrators," 2003.

http://ec.europa.eu/transport/logistics/documentation/freig ht_integrators/doc/final_report_freight_integrators.pdf

[17] P. Evers, D. Harper and P. Needham, “The Determinants of Shipper Perceptions of Modes," Transportation Jour- 
nal, Vol. 36, No. 2, 1996, pp. 13-25.

[18] A. Bryman and E. Bell, "Business Research Methods," Oxford University Press, Oxford, 2003.

[19] J. Floden, F. Bärthel and E. Sorkina, "Modal Choice in Europe-A Literature Review from the Transport Cus- tomers’ Perspective,” 2010.

http://130.241.192.19/Files/foretagsekonomi/LoT/Johan/P ublications/Reviewed_articles/ 1994_IFAC_Controllability.pdf 